\title{
ANALISIS KANDUNGAN MERKURI DAN HIDROKUINON PADA KRIM PEMUTIH TANPA IZIN EDAR YANG BEREDAR DIKOTA PALU
}

\section{Rayu Indri Pangesti dan Jamaluddin}

Universitas Tadulako, Palu, Sulawesi Tengah, Indonesia

Email:Indhry98@gmail.com dan jamal_farmasi02@yahoo.co.id

\begin{abstract}
This study aims to determine the content and amount of mercury $(\mathrm{Hg})$ and hydroquinone levels in whitening creams seen in traditional markets in Palu City. The sample of facial whitening cream under study was taken based on the purposive sampling method with the criteria of the sample that did not have a registration number, did not have an MUI halal certificate, did not contain active ingredients and did not have a BPOM number. Testing of hydroquinone levels was carried out using the Gas Chromatography-Mass Spectrometry (KGSM) method and testing for mercury (Hg) levels using the Atomic Absorption Spectrophotometer (AAS) method along with the additional MVU (Mercury Vaporizer Unit) method. Based on the measurement results, it was found that the highest levels of mercury $(\mathrm{Hg})$ were sample $B=44.06 \mu \mathrm{g} / \mathrm{g}$ and the lowest was sample $G=13.89 \mu \mathrm{g} / \mathrm{g}$ and the results of hydroquinone levels were all negative. Of all the samples that have been studied all contain mercury $(\mathrm{Hg})$ and negative contain hydroquinone.
\end{abstract}

Keywords: whitening face cream; mercury; hidroquinon; gas chromatography-mass spectrometry; atomic absorption spectrophotometer

\begin{abstract}
Abstrak
Penelitian ini bertujuan untuk mengetahui adanya kandungan dan jumlah kadar merkuri $(\mathrm{Hg})$ dan hidrokuinon pada sediaan krim pemutih wajah yang beredar di pasar tradisional Kota Palu. Sampel krim pemutih wajah yang diteliti diambil berdasarkan metode purposive sampling dengan kriteria sampel yang tidak memiliki nomor registrasi, tidak memiliki sertifikat halal MUI, tidak mencantumkan kandungan bahan aktif serta tidak memiliki nomor BPOM. Pengujian kadar hidrokuinon dilakukan dengan menggunakan metode Kromatografi Gas-Spektrometri Massa (KGSM) dan pengujian kadar merkuri (Hg) menggunakan metode Spektrofotometer Serapan Atom (SSA) beserta alat tambahan MVU (Mercury Vaporizer Unit). Berdasarkan hasil pengukuran didapatkan kadar merkuri $(\mathrm{Hg})$ paling tinggi yaitu sampel $\mathrm{J}=3481 \mu \mathrm{g} / \mathrm{g}$ dan terendah sampel $\mathrm{F}=1,035 \mu \mathrm{g} / \mathrm{g}$ dan hasil kadar hidrokuinon semua sampel tidak ada yang positif. Dari semua sampel yang telah diteliti semuanya positif mengandung merkuri $(\mathrm{Hg})$ dan negatif mengandung hidrokuinon.
\end{abstract}

Kata kunci: krim pemutih wajah; merkuri; hidrokuinon; kromatografi gas-spektrometri massa; spektrofotometer serapan atom; mercury vaporizer unit 


\section{Pendahuluan}

Kecantikan merupakan benteng pertahanan perempuan yang sekarang diserang industri kecantikan, setelah perempuan mendapat hak-haknya sebagaiwarga negara yang setara dengan laki-laki (Winarni, 2015).

Krim pemutih merupakan campuran bahan kimia dan atau bahan lainnya dengan khasiat bisa memutihkan kulit atau memucatkan noda hitam pada kulit. Krim tersebut sangat bermanfaat bagi wajah yang memiliki berbagai masalah di wajah karena mampu mengembalikan kecerahan kulit dan mengurangi warna hitam pada wajah. Sehingga, merupakan salah satu jenis kosmetik yang sangat popular di kalangan wanita karena menjanjikan dapat memutihkan atau menghaluskan wajah dalam waktu yang singkat (Erasiska, Bali, \& Hanifah, 2015).

Bahan-bahan yang sengaja dimasukkan ke dalam krim pemutih wajah yang dapat membahayakan tubuh seperti merkuri, hidrokuinon dengan konsentrasi lebih dari $2 \%$, asam retinoad dan bahan berbahaya lainnya. Bahan berbahaya tersebut sengaja dimasukan kedalam krim pemutih karena saat ini banyak anggapan menjadi cantik itu dengan kulit putih, mulus dan bercahaya. dengan anggapan demikian maka timbulah berbagai macam perawatan kulit yang komposisinya tidak sesuai dengan peraturan perundang-undangan yang telah ditetapkan. Banyak orang beranggapan bahwa kosmetik tidak akan menimbulkan hal-hal yang akan membahayakan karena hanya dioleskan di bagian luar. Padahal kulit mampu menyerap bahan yang dioleskan pada kulit. Sehingga, banyak produsen yang menggunakan bahan berbahaya dengan kadar yang melebihi ketentuan dan konsumen dapat langsung merasakan hasilnya dengan waktu yang singkat (Arisha Tanti, 2018).

Penggunaan bahan berbahaya dalam krim pemutih wajah dapat membahayakan kesehatan penggunanya. Pemakaian krim pemutih yang mengandung bahan berbahaya memang menjadikan kulit putih mulus kemudian akan mengendap dibawah kulit dan setelah bertahun-tahun akan berubah menjadi biru kehitaman dan akan memicu timbulnya kanker. Krim yang mengandung bahan berbahaya biasanya dijual dengan harga yang terjangkau dan menjanjikan hasil yang memuaskan. Krim tersebut biasanya tidak mencantumkan kandungan bahan kimia, penandaan, efek samping dan tanggal kadaluarsa (Handayana, 2019).

Peredaran kosmetik di Indonesia harus didaftarkan untuk mendapatkan izin edar dari BPOM RI. Produk yang tidak memiliki izin edar tidak boleh diedarkan dan akan mendapatkan sanksi administrative berupa pemusnahan produk. Setiap produk harus memiliki izin edar BPOM sesuai standar yang telah ditetapkan, syarat produk yang legal yaitu memiliki kode registrasi BPOM RI, memiliki sertifikat halal MUI dan memiliki kandungan bahan aktif yang tidak berbahaya (Hermanu, 2016).

Berdasarkan hasil survey (Badan Pengawasan Obat dan Makanan Republik Indonesia, 2018) telah menemukan 121 kosmetik ilegal dan/atau mengandung bahan dilarang (BB) seperti merkuri dan hidrokuinon. Dari hasil observasi yang telah dilakukan di Pasar Kota Palu terdapat 10 produk krim pemutih wajah ilegal Tanpa Izin Edar (TIE) yang dilarang pengunaannya karena mengandung bahan berbahaya. Sehingga, Hal inilah yang mendorong peneliti untuk melakukan penelitian terhadap 
logam merkuri $(\mathrm{Hg})$ dan hidrokuinon pada sediaan krim pemutih wajah Tanpa Izin Edar (TIE) yang beredar dipasar tradisional Kota Palu. Berdasarkan penelitian ini dapat dijadikan gambaran mengenai kualitas, keamanan dan mutu dari produk krim pemutih wajah yang beredar dimasyarakat.

Penelitian ini bertujuan untuk mengetahui sediaan krim pemutih wajah yang beredar dipasar tradisional Kota Palu mengandung merkuri $(\mathrm{Hg})$ dan hidrokuinon serta mengetahui kadar merkuri (Hg) dan hidrokuinon yang terkandung dalam sediaan krim pemutih wajah. Penelitian ini bermanfaat untuk menambah pengetahuan serta wawasan dan pengalaman bagi peneliti serta untuk instant yang sebagai masukkan guna menambah pengawasan kosmetik dan obat-obatan yang beredar dimasyakat. Dan diharapkan khususnya kepada para kaum wanita untuk lebih berhati-hati dalam memilih produk kosmetik yang aman.

\section{Metode Penelitian}

Penelitian yang dilakukan merupakan penelitian dengan Metode Deskriptif yaitu penelitian untuk memecahkan masalah yang diselidiki dengan meggambarkan keadaan subjek atau objek sesuai pencarian fakta dan Metode Analisis yaitu Analisis Kuantitatif yaitu penelitian yang dilakukan untuk mengetahui kadar suatu senyawa dalam suatu sampel. Sampel yang akan diteliti berupa krim pemutih wajah tanpa izin edar (TIE) yang beredar dipasar tradisional Kota Palu sebanyak 10 sampel.

\section{Hasil dan Pembahasan}

\section{Hasil Penelitian}

Hasil analisis merkuri ( $\mathrm{Hg}$ ) pada sediaan krim pemutih wajah dengan menggunakan metode Spektrofotometri Serapan Atom (SSA). Dari sepuluh sampel yang telah dipreparasi kemudian dilakukan pengukuran kandungan logam dalam krim pemutih wajah dapat dilihat pada Tabel 1 Dari tabel 1 Menunjukkan bahwa kandungan merkuri $(\mathrm{Hg})$ yang tertinggi pada sampel krim pemutih wajah B (44,06 $\mu \mathrm{g} / \mathrm{g})$ yang terendah pada sampel krim pemutih wajah $\mathrm{G}(13,89 \mu \mathrm{g} / \mathrm{g})$.

Tabel 1

Hasil analisis kuantitatif merkuri (Hg) menggunakan spektrofotometri Serapan

Atom (SSA)

\begin{tabular}{ccccccc}
\hline No & Sampel & $\begin{array}{c}\text { Berat } \\
\text { Sampel }(\mathrm{g})\end{array}$ & Absorbansi & Konsentrasi & $\begin{array}{c}\text { Kadar } \\
(\mu g / \mathrm{ml})\end{array}$ & $\begin{array}{c}\text { Kadar } \\
(\mu g l g)\end{array}$ \\
\hline 1. & $\mathrm{~A}$ & 1,0159 & 0,3099 & 25,4589 & 0,0254589 & 22,20 \\
\hline 2. & $\mathrm{~B}$ & 1,0478 & 0,2182 & 17,8489 & 0,0178489 & 17,03 \\
\hline 3. & $\mathrm{C}$ & 1,0430 & 0,5555 & 45,8406 & 0,0458406 & 44,06 \\
\hline 4. & $\mathrm{D}$ & 1,0468 & 0,3631 & 29,8738 & 0,0298738 & 28,53 \\
\hline 5. & $\mathrm{E}$ & 1,0625 & 0,3217 & 26,4381 & 0,0264381 & 24,88 \\
\hline 6. & $\mathrm{~F}$ & 1,0591 & 0,1349 & 10,9360 & 0,0109360 & 15,99 \\
\hline 7. & $\mathrm{G}$ & 1,0723 & 0,1827 & 14,9029 & 0,0149029 & 13,89 \\
\hline 8. & $\mathrm{H}$ & 1,0317 & 0,2200 & 17,9983 & 0,0179983 & 17,44 \\
\hline 9. & $\mathrm{I}$ & 1,0596 & 0,4534 & 37,3076 & 0,0373076 & 35,26 \\
\hline 10. & $\mathrm{~J}$ & 1,0393 & 0,5481 & 45,2265 & 0,0452265 & 43,51 \\
\hline
\end{tabular}

Ket : kode sampel A krim pemutih, B krim pemutih, C krim pemutih, D krim pemutih, E krim pemutih, F krim pemutih, $G$ krim pemutih, $\mathrm{H}$ krim pemutih, I krim pemutih dan J krim pemutih. 
Hasil analisis hidrokuinon pada sediaan krim pemutih wajah dengan menggunakan metode Kromatografi Gas-Spektroskopi Massa (KG-MS). Didapatkan hasil dari sepuluh sampel A, B, C, D, E, F, G, H, I, J yang telah dilakukan pengujian dapat dilihat pada Tabel 2. Dari Tabel 2 dapat diketahui bahwa pengujian hidrokuinon pada sepuluh sampel krim pemutih wajah negatif mengandung hirokuinon.

Tabel 2.

Hasil analisis kuantitatif hidrokuinon menggunakan Kromatografi Gas- Spektroskop Massa (KG-MS)

\begin{tabular}{ccccccc}
\hline No. & Sampel & $\begin{array}{c}\text { Berat } \\
\text { Sampel }(\mathrm{g})\end{array}$ & Area & Area $\%$ & RT & Probability \\
\hline 1. & A & 1,5041 & - & - & - & - \\
\hline 2. & B & 1,5069 & - & - & - & - \\
\hline 3. & C & 1,5068 & - & - & - & - \\
\hline 4. & D & 1,5071 & - & - & - & - \\
\hline 5. & E & 1,5011 & - & - & - & - \\
\hline 6. & F & 1,5035 & - & - & - & - \\
\hline 7. & G & 1,5040 & - & - & - & - \\
\hline 8. & H & 1,5066 & - & - & - & - \\
\hline 9. & I & 1,5027 & - & - & - & - \\
\hline 10. & J & 1,5089 & - & - & - & - \\
\hline
\end{tabular}

Ket : kode sampel A krim pemutih, B krim pemutih, C krim pemutih, D krim pemutih, E krim pemutih, F krim pemutih, G krim pemutih, $\mathrm{H}$ krim pemutih, I krim pemutih dan J krim pemutih

\section{Pembahasan}

Analisis kandungan merkuri dan hidrokuinon pada krim pemutih wajah dilakukan dengan pengujian kualitatif dan kuantitatif. Untuk pengujian kualitatif dan kuantitatif hidrokuinon pada krim pemutih wajah sampel menggunakan metode Kromatografi Gas-Spektrometri Massa (KGMS) penggunaan alat ini dimasuksudkan untuk menganalisa senyawa yang dapat diuapkan dan tidak terdekomposisi, memiliki resolusi dan sensitivitas tinggi, spesifik, fleksibel, dapat memberikan informasi struktur dan efisien. Serta merupakan alat yang dapat menguji kualitatif dan kuantitatif sekaligus, salah satunya adalah senyawa yang akan diuji pada sediaan krim pemutih wajah ini yaitu hidrokuinon, senyawa ini yang pada suhu tinggi dapat menguap dan memiliki gugus benzen serta terdapat kromofor yaitu senyawa organik yang memiliki ikatan rangkap terkonjugasi pada strukturnya sehingga memenuhi syarat untuk dianalisis menggunakan alat ini. Sedangkan pengujian senyawa merkuri (Hg) menggunakan metode Spektrofotometer Serapan Atom (SSA) penggunaan alat ini dimaksudkan untuk mengukur kadar logam salah satunya merkuri berdasarkan penyerapan cahaya oleh atom. Metode Spektrofotometri Serapan Atom dipilih karena memiliki tingkat kepekaan, ketelitian dan selektivitas yang tinggi dalam analisis logam, serta waktu pengerjaannya lebih singkat dan sederhana. juga mengapa merkuri menggunakan alat ini karenalogam merkuri mudah menguap sehingga analisis dalam mesin SSA dilakukan dengan sistem tanpa nyala (flameless) dengan panjang gelombang $253,7 \mathrm{~nm}$. Ini dipilih karena pada panjang gelombang 
tersebut memiliki sensitivitas yang paling baik tanpa terpengaruh dengan logam lainnya yang ada dalam sampel dan sangat sensitif mengukur kadar merkuri dalam jumlah sangat kecil (Jatmiko, Tjiptasurasa, 2011).

Pada pengujian hidrokuinon menggunakan metode Kromatografi GasSpektrometri Massa (KGSM), sampel dilarutkan menggunakan etanol sebagai pelarut polar. Penggunaan pelarut tersebut karena dapat mengikat senyawa hidroksil seperti hidrokuinon sehingga, senyawa tersebut tidak mudah teroksidasi dalam udara terbuka. Lalu ditambahkaan sodium sulfat tujuannya untuk menghilangkan sisa air setelah dilakukan pendinginan.

Dan pengujian merkuri menggunakan metode Spektrotometer Serapan Atom (SSA). Sampel dilarutkan menggunakan $\mathrm{HNO}_{3}$. Penggunaan pelarut ini karena merupakan asam yang paling efektif dan paling sering digunakan dalam dekstruksi basah yang mana dapat memecah sampel menjadi senyawa yang dapat terurai dan larutan ini sendiri sukar menguap sehingga digunakan pelarut tersebut dalam penelitian ini (Kartikasari, 2016).

Penggunaan metode dekstruksi basah, tujuannya adalah untuk memutuskan ikatan senyawa organik dalam sampel krim pemutih wajah menjadi bentuk logam yang dapat dianalisis, sehingga memudahkan dalam menganalisis unsur yang akan ditentukan, karena pada umunya metode ini digunakan untuk analisis logam-logam berat beracun yang tidak tahan pemanasan tinggi (mudah menguap) (Yulia, Putri, \& Hevira, 2019).

Asam nitrat $\left(\mathrm{HNO}_{3}\right)$ pekat dengan merkurium yang berlebihan menghasilkan ion merkurium(I): Reaksi yang terjad antara logam merkuri dengan $\mathrm{HNO}_{3}$ pekat adalah:

$$
\longrightarrow 6 \mathrm{Hg}+8 \mathrm{HNO}_{3} \uparrow \quad 3 \mathrm{Hg}_{2}{ }^{2+} 2 \mathrm{NO}+6 \mathrm{NO}_{3}-4+4 \mathrm{H}_{2} \mathrm{O}
$$

Dengan asam nitrat $\left(\mathrm{HNO}_{3}\right)$ pekat yang panas berlebihan, terbentuk ion merkurium (II):

$$
\rightarrow 3 \mathrm{Hg}+8 \mathrm{HNO}_{3} \uparrow 3 \mathrm{Hg}^{2+}+2 \mathrm{NO}+6 \mathrm{NO}_{3}^{-}+4 \mathrm{H}_{2} \mathrm{O}
$$

Merkuri ( $\mathrm{Hg}$ ) bersifat sangat berbeda terhadap reagensia-reagensia yang dipakai dalam analisis kualitatif dan karenanya masuk kedalam dua golongan analit yang berlainan. Ion merkurium (I) masuk dalam golongan kation pertama, dilain pihak ion-ion merkurium (II) berada dalam golongan kation ke dua(Vogel, 1985).

Larutan sampel hasil dekstruksi basah dilakukan uji kuatitatif menggunakan dua reagen, yaitu larutan $\mathrm{H}_{2} \mathrm{SO}_{4}$ dan $\mathrm{SnCl}_{2}$. Penggunaan kedua reagen ini digunakan karena mengalisis $\mathrm{Hg}$ dilakukan tanpa nyala sehingga larutan sampel harus direduksi lebih dahulu dengan campuran reagen tersebut (Khopkar, 2002).

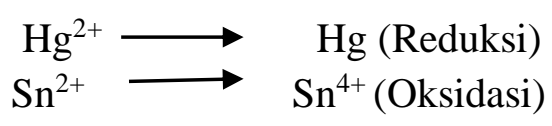

$$
\mathrm{Hg}^{2+}+\mathrm{Sn}^{2+} \longrightarrow \quad \mathrm{Hg}+\mathrm{Sn}^{4+}
$$


Hasil pengukuran kurva kalibrasi standar baku merkuri menghasilkan persamaan regresi $\mathrm{y}=0,01205+0,00312$ dengan nilai $\mathrm{a}=0,00312 \mathrm{~b}=0,01205$ dan nilai $\mathrm{r}=$ 0,9994. Berdasarkan nilai koefisien korelasi yang dihasilkan mendekati nilai 1 yang artinya hubungan linear yang ideal jika nilai $r=+1$ atau -1 tergantung pada arah garis. Nilai koefisien korelasi yang memenuhi persyaratan mendekati 1 menunjukkan adanya hubungan yang linear antara absorbansi yang terukur dengan konsentrasi analit sehingga, metode ini cukup akurat dalam menentukan kadar merkuri dalam suatu larutan sampel karena memenuhi kriteria penerimaan yaitu $0,99 \leq \mathrm{r}<1$ dan baik digunakan untuk analisis merkuri (Hg) dengan hasil yang baik (Harmita, 2004).

Hasil pengukuran pada Tabel 1 Tentang analisis kuantitatif kadar merkuri pada sampel krim pemutih wajah menunjukkan adanya senyawa merkuri $(\mathrm{Hg})$ pada semua sampel dengan kadar paling tinggi yaitu pada kode sampel $\mathrm{C}$ sebesar 44,06 $\mu \mathrm{g} / \mathrm{g}$ dan kadar merkuri paling rendah yaitu pada kode sampel G sebesar 13,89 $\mu \mathrm{g} / \mathrm{g}$, sehingga, penggunaan krim pemutih wajah yang mengandung merkuri sangat tidak boleh dianjurkan untuk digunakan. Hasil menunjukkan positif karena metode yang digunakan dapat mendeteksi merkuri hingga kadar yang sangat kecil yaitu $0,16 \mu \mathrm{g} / \mathrm{mL}$ dan merupakan alat yang digunakan untuk menganalisis logam beradengan tingkat ketelitian yang tinggi dan selektif. Berdasarkan 10 sampel yang diambil dari pasar tradisional di Kota Palu semua terbukti positif mengandung merkuri sehingga sediaan krim pemutih wajah tersebut tidak aman untuk digunakan pada kulit dan sangat berbahaya karena bersifat toksik dan karsinogen bagi tubuh walaupun digunakan dalam konsentrasi kecil. Dengan maraknya produk krim pemutih wajah yang beredar tidak aman digunakan karena mengandung merkuri, banyak produsen yang menambahkan senyawa tersebut dengan jumlah yang berbeda-beda tiap produk. Sehingga ketika krim pemutih wajah berbahaya yang mengandung merkuri dengan jumlah besar maka hanya dibutuhkan waktu 3-5 hari untuk dapat memutihkan wajah dengan cepat.

Dari hasil analisis Tabel 2 Tentang analisis kualitatif dan kuantitatif kadar hidrokuinon pada sampel krim pemutih wajah menunjukan tidak adanya sampel yang mengandung hidrokuinon. Diketahui bahwa dari kesepuluh sampel yang telah diuji semuanya tidak terdekteksi mengandung hidrokuinon, berdasarkan hasil analisis GCMS komponen senyawa hidrokuinon dengan penguapan $>100^{\circ} \mathrm{C}$ tidak menunjukkan adanya senyawa tersebut. Hal ini dikarenakan hasil yang didapatkan dari GC kemudian dimasukkan dalam instrument MS, sehingga diperoleh informasi mengenai massa molekul relatif dari senyawa sampel, massa molekul dari senyawa hidrokuinon adalah 110 sehingga dari massa molekul relatif hidrokuinon tersebut tidak sama dengan sampel yang diuji. Berdasarkan BPOM RI (2007) kadar hirokuinon dalam krim yang beredar dipasaran hanya diperbolehkan $2 \%$, lebih dari itu digunakan sebagai obat dengan resep dokter. Sehingga, hidrokuinon masih aman jika digunakan dengan kadar yang ditentukan dalam krim pemutih wajah yang dijual dipasaran.

Sesuai dalam Peraturan (Badan POM RI, 2011) Nomor KH.03.1.23.08.11.07517 tentang persyaratan teknis bahan kosmetika merkuri tidak boleh ditambahkan sama sekali karena merkuri dan senyawanya termasuk dalam daftar kosmetik yang dilarang. Penelitian yang dilakukan oleh (Rohaya, Ibrahim, \& Jamaluddin, 2017) di Kota Palu 
hasil menunjukkan dari sepuluh sampel yang di uji mengandung merkuri dengan kadar yang tinggi. Penelitian lain yang dilakukan oleh (Rahma Yulia, 2019) di Kota Bukit Tinggi hasil analisis menunjukkan bahwa kelima sampel krim pemutih wajah yang diteliti mengandung merkuri setelah dilakukan uji kualitatif dan kuantitatif. Dan dari kelima sampel mengandung merkuri melebihi batas aman yang diperbolehkan BPOM RI, sehingga bila digunakan dalam jangka waktu lama dapat menimbulkan efek karsinogen dan teratogen. Dan penelitian lain yang dilakukan oleh (Simaremare, 2019) di Kota Jayapura hasil analisis menunjukkan bahwa pada delapan sampel yang beredar positif mengandung merkuri dan enam diantaranya positif mengandung hidrokuinon. Dilihat dari penelitian yang telah dilakukan sekarang maupun penelitian terdahulu produk-produk yang beredar di Pasar Tradisional Indonesia khususnya Palu dan penelitian sebelumnya yang dilakukan di Kota BukitTinggi dan jayapura menunjukkan bahwa banyak produk yang dijual dipasaran tidak aman untuk digunakan. Sehingga, konsumen harus lebih berhati-hati dalam memilih jenis kosmetik krim pemutih wajah yang dijual dipasar tradisional.

Sebagaimana telah diketahui bahwa logam merkuri adalah salah satu logam berat yang sangat beracun. Pengaruh utama yang ditimbulkan oleh merkuri didalam tubuh adalah menghalangi kerja enzim dan merusak selaput dinding sel. Merkuri yang terkandung dalam krim pemutih wajah dapat masuk kedalam tubuh dengan jalan terserap melalui kulit. Pemakaian krim pemutih wajah yang terkandung merkuri akan menjadikan kulit putih mulus, namun kemudian akan mengendap dibawah kulit dan setelah bertahun-tahun kulit akan menjadi biru kehitaman, bahkan dapat memicu timbulnya kanker. Efek berbahaya penggunaan merkuri dalam waktu singkat dapat menyebabkan iritasi parah pada kulit, yakni berupa kulit yang kemerah-merahan dan menyebabkan kulit menjadi mengkilap secara tidak normal, muncul flek hitam dan kulit menjadi kusam dan lambat laun akan berubah menjadi flek yang tambah parah, berubah keabu-abuan selanjutnya kehitaman bila pemakaian dihentikan. Dan efek berbahaya dalam jangka panjang dapat memperlambat pertumbuhan janin mengakibatkan keguguran, kematian janin dan mandul, keracunan bila digunakan dalam jangka waktu panjang, dapat berakibat terjadinya gagal ginjal bahkan dapat memicu timbulnya kanker. Pemakaian krim pemutih wajah yang terkandung merkuri akan menjadikan kulit putih mulus, namun kemudian akan mengendap dibawah kulit dan setelah bertahuntahun kulit akan menjadi biru kehitaman, bahkan menimbulkan efek karsinogen dan teratogen (Rasyid, 2005).

Berdasarkan (PerMenKes RI No.445/MenKes/PER/V/1998)Tentang Bahan, Zat Warna, Substratum, Zat Pengawet dan Tabir Surya Pada Kosmetik dan Keputusan Kepala Badan POM No.HK.00.05.4.1745 Tentang Kosmetik bahwa merkuri dan senyawanya adalah salah satu bahan yang dilarang digunakan dalam produk kosmetik kecuali fenil raksa sebagai bahan pengawet untuk sediaan mata dengan konsentrasi 0,007\% (Badan Pengawasan Obat dan Makanan Republik Indonesia, 2007). 


\section{Kesimpulan}

Berdasarkan hasil penelitian yang telah dilakukan dapat disimpulkan bahwa : (1.) Dari semua sampel krim pemutih wajah yang telah di uji kesepuluh sampel dinyatakan positif mengandung merkuri $(\mathrm{Hg})$ dan negatif mengandung hidrokuinon. (2.) Kadar merkuri $(\mathrm{Hg})$ dari kesepuluh sampel yang telah di teliti didapatkan hasil masing-masing sampel $\mathrm{A}=22,20 \mu \mathrm{g} / \mathrm{g}, \mathrm{B}=17,03 \mu \mathrm{g} / \mathrm{g}, \mathrm{C}=44,06 \mu \mathrm{g} / \mathrm{g}, \mathrm{D}=28,53 \mu \mathrm{g} / \mathrm{g}, \mathrm{E}=24,88$ $\mu \mathrm{g} / \mathrm{g}, \mathrm{F}=15,99 \mu \mathrm{g} / \mathrm{g}, \mathrm{G}=13,89 \mu \mathrm{g} / \mathrm{g}, \mathrm{H}=17,44 \mu \mathrm{g} / \mathrm{g}, \mathrm{I}=35,26 \mu \mathrm{g} / \mathrm{g}$ dan $\mathrm{J}=43,51$ $\mu \mathrm{g} / \mathrm{g}$.

\section{BIBLIOGRAFI}

Arisha Tanti. (2018). Kamus muslimah cerdas. PT Elex Media Komputindo: Jakarta.

Badan Pengawasan Obat dan Makanan Republik Indonesia. (2007). No Title. In kenalilah kosmetik sebelum menggunakannya: Vol. VIIIno.4. Jakarta.

Badan Pengawasan Obat dan Makanan Republik Indonesia. (2018). No Title. In Lampiran Public Warning No. B-HM.01.01.1.44.11.18.5410 Tentang Kosmetik Mengandung Bahan Berbaya. Jakarta.

Badan POM RI. (2011). Peraturan Kepala Badan Pengawasan Obat dan Makanan Republik IndonesianNomor HK.03.1.23.08.11.07331 Tahun 2011 Tentang Metode Analisis Kosmetika. Jakarta.

Erasiska, Erasiska, Bali, Subardi, \& Hanifah, Tengku Abu. (2015). Analisis kandungan logam timbal, kadmium dan merkuri dalam produk krim pemutih wajah. Riau University.

Handayana, Fitri. (2019). Faktor-faktor yang berhubungan dengan penggunaan krim pemutih pada mahasiswi di fakultas kesehatan masyarakat Universitas Muhammadiyah Aceh Tahun 2019.

Harmita. (2004). Petunjuk Pelaksanaan Validasi, Metode dan Cara Perhitungannya. Jakarta: FMIPA Universitas Indonesia.

Hermanu, Bambang. (2016). Studi implementasi izin edar produk pangan industri rumah tangga (pirt) dalam mewujudkan keamanan pangan yang optimal di kota semarang. Jurnal Ilmiah Hukum Dan Dinamika Masyarakat, 11(2).

Jatmiko, Tjiptasurasa, dan Wiranti. (2011). Analisis Merkuri Dalam Sediaan Kosmetik Body lotion Menggunakan Metode Spektrofotometri Serapan Atom. Fakultas Farmasi UMP. Purwokerto, Vol. 8, No. 
Analisis kandungan merkuri $(\mathrm{Hg})$ dan hidrokuinon pada sediaaan krim pemutih wajah

Kartikasari, Melinda. (2016). Analisis logam timbal (Pb) ada buah apel (Pylus Malus l.) dengan metode destruksi basah secara Spektrofotometri serapan atom. Universitas Islam Negeri Maulana Malik Ibrahim.

Khopkar. (2002). Konsep Dasar Kimia Analitik. Jakarta: Universitas Indonesia Press.

Permenkes RI. (1998). bahan, zat warna. substratum, zat pengawet dan tabir surya pada kosmetik. Peraturan Menteri Kesehatan Republik Indonesia No. 445/MenKes/Permenkes/1998.

Rahma, Yulia. (2019). Analisis Merkuri Pada Merk Krim Pemutih Wajah Dengan Metode Spektrofotometri Serapan Atom. Katalisator, Vol. 4 No., 103-110.

Rasyid. (2005). Pemeriksaan Kualitatif Hidrokuinon dan Merkuri Dalam Krim Pemutih. Farmasi Higea, Vol. 7 No.

Rohaya, Upik, Ibrahim, Nurlina, \& Jamaluddin, Jamaluddin. (2017). Analisis Kandungan Merkuri (Hg) Pada Krim Pemutih Wajah Tidak Terdaftar Yang Beredar Di Pasar Inpres Kota Palu. Jurnal Farmasi Galenika (Galenika Journal of Pharmacy), 3(1), 77-83.

Simaremare, Eva Susanty. (2019). Analisis Merkuri Dan Hidrokuinon Pada Krim Pemutih Yang Beredar Di Jayapura. JST (Jurnal Sains Dan Teknologi), 8(1), 1.

Vogel. (1985). Analisis Anorganik Kualitatif makro dan semimakro. Jakarta: PT. Kalman Media Pustaka.

Winarni, Rina Wahyu. (2015). Representasi Kecantikan Perempuan dalam Iklan. Deiksis, 2(02), 134-152.

Yulia, Rahma, Putri, Annisa, \& Hevira, Linda. (2019). Analisis Merkuri Pada Merk Krim Pemutih Wajah dengan Metode Spektrofotometri Serapan Atom. Jurnal Katalisator, 4(2), 103-110. 